\title{
Adverse Effects of Dangerous Drugs to Out-of-School Youth
}

\author{
Shirley S Domingo, RCrim, DPA, PhD.Crim* \\ ttinglesunday@yahoo.com \\ Tuguegarao City, Cagayan 3500 Philippines
}

Abstract

Drug and substance abuse is an ever-expanding problem around the globe today and is recognized as a threat with serious effects on an individual's health, security, social-economic and cultural welfare. Looking into the present program of Duterte's administration, his election campaign up to the time when he occupies the highest seat in Malacanan, the promise of six (6) months of all-out war on the drug did not prosper but it is still his priority despite many concerns that are entangled in serving the Filipino people as his main agenda in addition to their safety day in and day out. Due to the prevalence of drugs in the black market, peddlers and street drug sellers are increasing and the demand is consistently high. Laws are enacted since this problem proliferate but no clear response and the answer was provided whether this has been resolved or not. Undeniably, the abuse of illegal drugs persisted in the Philippines. Young minds of the youth are distorted and professionals are becoming a liability to their organization.

As mentioned by Abdulkarim (2005), students have shown consistently a considerable prevalence of drug substance using which varies in places, rates, kinds, types of users, and the actions as results of drug abuse in Nigeria.

It is apparent and very evident that drug use and abuse in the Philippines as shown in the daily news published by the different news agencies and pronounced by the journalist is still a major problem despite the many laws and various measures taken by the concerned agencies of the government to curb it and awareness is at stake because many youngsters are still wanting to try due to curiosity, and proper information is very significant and the researcher believes one of the strategies in the reduction of drug users. Knowing the effect is already a warning.

In one of the cities in Cagayan Valley where the study was conducted the out-of-school youth is one of the concentrations being addressed of every local government unit officers particularly at the barangay level. From the selected identified barangays where the presence of out-of-school youth is high and was identified as trying to start and indulge in drug-using and selling. All these are glitches that created other and varied problems for the community's stakeholders that affected the peace and order and tranquillity. Everyone aims to be living in a peaceful society. Drug use, drunkenness, gambling, and prostitution are instrumental to the easy target including recruitment. With the foregoing 
problems relative to drug use and abuse, the researcher looked into the level of awareness of the out-ofschool youth in the adverse effects of drug use and abuse because she believes that when a young mind is not busy, it tends to be thinking of something that will make the brain works be it legal or illegal, productive or non-productive during the day.

Keywords: Type your keywords here, separated by semicolons ; Level of Awareness; Adverse effect; drug abuse; Out-ofSchool Youth(OSY)

\section{Main text}

The study was about the assessment on the adverse effect of dangerous drugs to the Out-of-School youth in one of the Cities in Cagayan Valley.

\section{Introduction}

In the globe today, drug and substance abuse is an ever-expanding problem and is recognized as a threat with serious effects on an individual's health, security, social-economic and cultural welfare. Looking into the present program of Duterte's administration, his election campaign up to the time when he occupies the highest seat in Malacanan, the promise of six (6) months of all-out war on the drug did not prosper but it is still his priority despite many concerns that are entangled in serving the Filipino people as his main agenda in addition to their safety day in and day out. Due to the prevalence of drugs in the black market, peddlers and street drug sellers are increasing and the demand is consistently high. Laws are enacted since this problem proliferate but no clear response and the answer was provided whether this has been resolved or not. Undeniably, the abuse of illegal drugs persisted in the Philippines. Young minds of the youth are distorted and professionals are becoming a liability to their organization.

Looking into the complexities of drug use, fighting, and violence inside and outside the home, money problems, trouble at school, trouble at work or losing a job, trouble in relationships, child abuse or neglect, driving crashes, and arrests and jail are some of the common adverse effects. Drug use can hurt the people who take drugs and the people around them, including families, kids, and babies who aren't born. The problem is that the drug being used can have a serious effect on the body and brain. Drug use can also lead to addiction, a long-lasting brain condition in which people cannot stop taking drugs. As mentioned by Abdulkarim (2005), students have shown consistently a considerable prevalence of drug substance using which varies in places, rates, kinds, types of users, and the actions as results of drug abuse in Nigeria.

It is apparent and very evident that drug use and abuse in the Philippines as shown in the daily news published by the different news agencies and pronounced by the journalist is still a major problem despite the many laws and various measures taken by the concerned agencies of the government to curb it and awareness is at stake because many youngsters are still wanting to try due to curiosity, and proper information is very significant and the researcher believes one of the strategies in the reduction of drug users. Knowing the effect is already a warning.

In one of the cities in Cagayan Valley where the study was conducted the out-of-school youth is 
Paradigm showing the profile Variables of the respondents being assessed, the process, and the outputs.

\section{$\underline{\text { Research Problem }}$}

The main objective of the study was to assess the level of awareness of the Out-of-School Youth on the adverse effects of dangerous drugs for CY 2019.

Specifically, it sought to answer the following questions:

1. What is the profile of the respondents relative to:

1.1. Age

1.2. Gender

1.3. Parent's Highest Educational Attainment

1.4. Parent's Occupation

1.5. Parent's Gross Income

1.6. Ethnicity

2. What is the level of awareness of the respondents on adverse effects of drugs relative to:

2.1. education

2.2. Health

2.3. Family

2.4. Behavior

3. Is there a significant relationship between the level of awareness of the respondents on the adverse effects of drugs and their profile variables?

4. In what dimension/s are the respondents not aware of?

5. What measures can be proposed to address the dimension where the respondents are not aware?

\section{Hypothesis}

This study was guided by a hypothesis that there is no significant relationship between the level of awareness on adverse effects of drugs and their profile variables.

\section{Significance of the study}

Findings from this research have several implications for the following.

LGU Officials. The results of this research will provide a baseline in the planning of a more cohesive program of activities for the Out-of-School youth in the locality.

Local legislators. The findings of this research study will help them enact laws relative to the protection of the Out-of-School youth in indulging in any form of vices particularly the use and abuse of dangerous drugs. Results can also be their basis in initiating programs intended for the youth who do not go to school for their education.

Parents of the OSY. The results will help them motivate their children to go to school and pursue their studies and or be trained in vocational schools.

Out-of-School Youth. The findings of this study may give the respondents a clearer vision of the importance of attending schools in order not to be vulnerable in indulging in different forms of 
vices like taking illegal drugs.

Community. The results of this study entail initiative from them to help the barangay officials institute programs intended for the youth.

Researcher. The result of this study provides great help in determining the level of awareness of the Out-Of-Schoo Youth considering their vulnerability to drugs and assessing if they are aware of the effects of taking illegal drugs.

Future Researchers. The result of this study provides future researchers important data for the conduct of similar studies where other variables can be included.

\section{$\underline{\text { Scope and Delimitation }}$}

The focus of this study was the assessment of the level of awareness of the Out-of-School Youth on the adverse effects of drugs in one of the cities of Cagayan Valley for CY 2019. The respondents were the one hundred twenty one (121) Out -of -School -Youth (OSY) from the twelve (12) select barangays located in the heart of the city. It involved the assessment on the level of awareness of the respondents on the adverse effects of drugs to the education, health, family and behavior.

\section{RESEARCH METHODOLOGY}

In as much as this study dealt with the assessment on the level of awareness of out-of-school youth on adverse effects of drugs; this undertaking used a descriptive correlational method of research because it determined the significance of the different parameters in the posted problem.

The data were treated with the use of a simple frequency count, percentage, and weighted mean. The frequency and percentage were used to determine the occurrence of conditions related to the study.

An inferential statistic was used to determine the correlation between the level of awareness of adverse effects of drugs and the profile variable of the OSY respondents.

\section{RESULTS}

1. Profile of the Respondents

1.1. Age

Table 1

Frequency and Percentage Distribution of the Out-of-School Youth Respondents in terms of Age

\begin{tabular}{c|c|c}
\hline Age Bracket & Frequency & Percentage \\
\hline $15-18$ & 11 & 9.10 \\
\hline $19-22$ & 101 & 83.50 \\
\hline $23-26$ & 9 & 7.40 \\
\hline Total & 121 & 100.00 \\
\hline
\end{tabular}

Mean age: 19.81 
As indicated in the table, 101 or $83.50 \%$ belong to the age bracket of $19-22$ while 9 or $7.40 \%$ of the respondents belong to the age bracket from 23-26. The mean age is 19.81 which implies that the OSY are in their early adulthood.

\subsection{Gender}

\section{Table 2}

Frequency and Percentage Distribution of the Out-of-School Youth Respondents in terms of Gender

\begin{tabular}{c|c|c}
\hline Gender & Frequency & Percentage \\
\hline Males & 100 & 82.60 \\
\hline Females & 21 & 17.40 \\
\hline Total & 121 & 100.00 \\
\hline
\end{tabular}

As shown above, 100 or $82.60 \%$ are males and 21 or $17.40 \%$ are females. This finding implies that the Out-of-School youth respondents are dominated during the conduct of this study.

\subsection{Civil Status}

\section{Table 3}

Frequency and Percentage Distribution of the Out-of-School Youth Respondents in terms of Civil Status

\begin{tabular}{c|c|c}
\hline Civil Status & Frequency & Percentage \\
\hline Single & 121 & 100.00 \\
\hline Married & 0 & 0.00 \\
\hline Total & 121 & 100.00 \\
\hline
\end{tabular}

As presented above, all of the respondents are single and none of them is married. This means that all of the respondents are single as indicated in their mean age of 19.81 .

1.3. Highest Educational Attainment of Parents

Table 4

Frequency and Percentage Distribution of the Out-of-School Youth Respondents in terms of Highest

Educational Attainment

Of Parents

\begin{tabular}{c|c|c}
\hline Educational Attainment & Frequency & Percentage \\
\hline Elementary Graduate & 68 & 56.20 \\
\hline College Graduate & 52 & 43.00 \\
\hline Masters Degree & 1 & 0.80 \\
\hline Total & 121 & 100.00 \\
\hline
\end{tabular}


As reflected above, the elementary graduate is the highest frequency with 68 or $56.20 \%$ of the respondents' parents which means that most of them are elementary graduates while master's degree is the lowest with a frequency of 1 or $0.80 \%$ of the respondents' parent, this means that majority of the parents of the respondents are elementary graduates.

1.4. Occupation of Parents

\section{Table 5}

Frequency and Percentage Distribution of the

Out-of-School Youth Respondents in terms of Occupation Of Parents

\begin{tabular}{c|c|c}
\hline Occupation & Frequency & Percentage \\
\hline Farmer & 68 & 54.80 \\
\hline Driver & 18 & 14.50 \\
\hline Office Worker & 10 & 8.10 \\
\hline Policeman & 3 & 2.40 \\
\hline Total & 121 & 100.00 \\
\hline
\end{tabular}

As reflected above, the highest is a farmer with 68 or $54.80 \%$ of the parents of the respondents which means that most of them are farmers since they did not finish college. The lowest is working as a policeman with 3 or $2.40 \%$ of the respondents' parents. This means that majority of the parents of the respondents are farmers since they did not finish college.

1.5. Parents' Gross Income

\section{Table 6}

Frequency and Percentage Distribution of the

Out-of-School Youth Respondents in terms of

Parents' Gross Income

\begin{tabular}{c|c|c}
\hline Income & Frequency & Percentage \\
\hline $100-10,000$ & 59 & 48.80 \\
\hline $10,001-20,000$ & 39 & 32.20 \\
\hline $20,001-30,000$ & 21 & 17.40 \\
\hline $30,001-$ above & 2 & 1.70 \\
\hline Total & 121 & 100.00 \\
\hline
\end{tabular}

As reflected above, 59 or $48.80 \%$ of the respondents are earning 100-10,000 monthly income and 2 or $1.70 \%$ of them are earning 30,001-above, this implies that most of the parents of the respondents are earning 100-10,000 monthly income because they are not permanent employees of any firm but working as farmers. 
1.6. Ethnic Affiliation

Table 7

Frequency and Percentage Distribution of the Respondents in terms of Ethnic Affiliation

\begin{tabular}{c|c|c}
\hline Ethnic & Frequency & Percentage \\
\hline Ilocano & 28 & 23.10 \\
\hline Itawes & 71 & 58.70 \\
\hline Ibanag & 11 & 9.10 \\
\hline Tagalog & 3 & 2.50 \\
\hline Kalinga & 8 & 6.60 \\
\hline Total & 121 & 100.00 \\
\hline
\end{tabular}

As reflected above, 71 or $58.70 \%$ of the respondents are Itawes and 3 or $2.50 \%$ respondents are Tagalog. This implies that the majority of the respondents are Itawes because the respondents belong to the Itawes speaking City. 
2. Level of Awareness of the Respondents on Adverse Effects of Drugs

2.1. Education

Table 8

Mean and Descriptive Scale on the Level of Awareness of the Respondents on Adverse Effects of Drugs relative to Education

\begin{tabular}{l|c|c}
\hline \multicolumn{1}{c|}{ Items } & Mean & Descriptive Scale \\
\hline 1. I am not interested to continue my studies & 2.41 & Very Much Aware \\
\hline 2. I do not like to attend classes & 2.21 & Aware \\
\hline $\begin{array}{l}\text { 3. I do not like to be doing my assignments when going to } \\
\text { school }\end{array}$ & 2.31 & Aware \\
\hline $\begin{array}{l}\text { 4. I want to stay at home due to a hangover or the effects of } \\
\text { drugs. }\end{array}$ & 2.33 & Aware \\
\hline $\begin{array}{l}\text { 5. I might attend my class for the sake of allowance in order } \\
\text { to have money to buy drugs. }\end{array}$ & 2.19 & Aware \\
\hline 6. I wanted to be with the group having a hangout & 2.32 & Aware \\
\hline 7. I want to try the effects of drugs & 2.30 & Aware \\
\hline \multicolumn{1}{c}{ Category Mean } & 2.30 & Aware \\
\hline
\end{tabular}

As presented above, respondents assessed item number 1 "I am not interested to continue my studies" with the highest mean of 2.41 or "Very Much Aware". It means that respondents agreed that they are not interested to continue their studies when they are taking illegal drugs. They have assessed Item number 5 "I might attend my class for the sake of allowance to have money to buy drugs." with the lowest mean of 2.19 or "Aware". It means that respondents are aware that those drug dependents attend classes just to have money out of their daily allowance to buy drugs.

A category mean of 2.30 or "Aware". It means that respondents are aware of the adverse effects of drugs in terms of education because it makes them lazy to continue their studies.

2.2. Health

Table 9

Mean and Descriptive Scale on the Level of Awareness of the Respondents on Adverse Effects of Drugs relative to Health

\begin{tabular}{rl|c|c}
\hline \multicolumn{1}{c|}{ Items } & Mean & Descriptive Scale \\
\hline 1. & \begin{tabular}{l}
\multicolumn{1}{c|}{ Indulgence in drugs increases the risk of heart attack } \\
and stroke.
\end{tabular} & 2.37 & Very Much Aware \\
\hline 2. & Drug causes lung cancer. & 2.45 & Very Much Aware \\
\hline 3. Drug causes HIV/AIDS. & 2.24 & Aware \\
\hline 4. Indulgence to drugs weakens the immune system. & 2.39 & Very Much Aware \\
\hline
\end{tabular}




\begin{tabular}{r|c|c}
\hline 5. Drug is addictive and hard to let go. & 2.33 & Aware \\
\hline 6. Drug causes death. & 2.40 & Very Much Aware \\
\hline Category Mean & 2.36 & Very Much Aware \\
\hline
\end{tabular}

As stated above, respondents assessed item number 5 "Drug causes lung cancer" with the highest mean of 2.45 or "Very Much Aware". It means that respondents agreed that drugs are a common cause of lung cancer. They have assessed Item number 3 "Drug causes HIV/AIDS" with the lowest mean of 2.24 or "Aware". It means that respondents are aware that drugs can also cause AIDS/HIV disease if prolong use.

A category mean of 2.36 or "Very Much Aware". It means that respondents are very much aware of the adverse effects of drugs in terms of health because they may cause long-term illnesses like lung cancer.

\subsection{Family}

Table 10

Mean and Descriptive Scale on the Level of Awareness of the Respondents on Adverse Effects of Drugs relative to Family

\begin{tabular}{|c|c|c|}
\hline Items & Mean & Descriptive Scale \\
\hline $\begin{array}{l}\text { 1. I am violent to my siblings if I'm under the influence } \\
\text { of drugs. }\end{array}$ & 2.35 & Very Much Aware \\
\hline 2. I disrespect my parents. & 2.40 & Very Much Aware \\
\hline 3. I only talk with my parents if I ask for money & 2.24 & Aware \\
\hline $\begin{array}{l}\text { 4. Stealing money from my parents become a hobby } \\
\text { just to have money to buy drugs. }\end{array}$ & 2.30 & Aware \\
\hline $\begin{array}{l}\text { 5. I am not able to maintain a harmonious relationship } \\
\text { with my family. }\end{array}$ & 2.31 & Aware \\
\hline 6. I don't have time with my family. & 2.15 & Aware \\
\hline 7. I got misunderstanding with my parents. & 2.31 & Aware \\
\hline 8. I always give a problem to my parents. & 2.12 & Aware \\
\hline Category Mean & 2.27 & Aware \\
\hline
\end{tabular}

As stated above, respondents assessed item number 2 "I disrespect my parents" with the highest mean of 2.40 or "Very Much Aware". It means that respondents agreed that taking drugs and their effects can change their behavior. They have assessed Item number 8 "I always give a problem to my parents" with the lowest mean of 2.12 or "Aware". It means that respondents are aware that taking drugs can cause problems for parents.

A category mean of 2.27 or "Aware". It means that respondents are aware of the adverse effects of drugs in terms of the family because it may bring additional problems to the family particularly to parents. 
2.4. Behavior

Table 11

Mean and Descriptive Scale on the Level of Awareness of the Respondents on Adverse Effects of Drugs

relative to Behavior

\begin{tabular}{|c|c|c|}
\hline Items & Mean & Descriptive Scale \\
\hline $\begin{array}{l}\text { 1. I easily get angry when I am under the influence of } \\
\text { drugs. }\end{array}$ & 2.35 & Very Much Aware \\
\hline $\begin{array}{l}\text { 2. I become a trouble maker once I'm under the } \\
\text { influence of drugs. }\end{array}$ & 2.27 & ware \\
\hline 3. I become irritated once that I cannot take drugs. & 2.38 & Very Much Aware \\
\hline 4. I get mad if my parents don't give me money. & 2.30 & Aware \\
\hline $\begin{array}{l}\text { 5. I love doing to party when I am under the influence } \\
\text { of drugs. } \\
\text { 6. It increases my confidence when I am under the } \\
\text { influence of drugs. }\end{array}$ & 2.31 & Aware \\
\hline 7. I don't sleep when I am under the influence of drugs. & 2.34 & Very Much Aware \\
\hline $\begin{array}{l}\text { 8. I become talkative when I am under the influence of } \\
\text { drugs. }\end{array}$ & 2.31 & Aware \\
\hline 9. I become crazy once that I cannot take drugs. & 2.35 & Very Much Aware \\
\hline $\begin{array}{l}\text { 10. I easily get angry when I am under the influence of } \\
\text { drugs. }\end{array}$ & 2.19 & \\
\hline Category Mean & 2.31 & Aware \\
\hline
\end{tabular}

As stated above, respondents assessed item number 3 "I become irritated once that I cannot take drugs" with the highest mean of 2.38 or "Very Much Aware". It means that respondents agreed that people using drugs are easy to get annoyed or irritated. They have assessed Item number 10 "I easily get angry when I am in the influence of drugs." with the lowest mean of 2.19 or "Aware". It means that respondents are aware that a person using drugs are sometimes cannot control his emotions.

A category mean of 2.31 or "Aware". It means that respondents are aware of the adverse effects of taking drugs in terms of behavior because can easily be annoyed or irritated.

\subsection{Summary Table}

Table 12

Summary Table on the Level of Awareness of the Respondents on Adverse Effects of Drugs

\begin{tabular}{c|c|c}
\hline Dimensions & Mean & Descriptive Scale \\
\hline Education & 2.30 & Aware \\
\hline Health & 2.36 & Very Much Aware \\
\hline Family & 2.27 & Aware \\
\hline Behavior & 2.31 & Aware \\
\hline
\end{tabular}


As stated above, Health got the highest mean of 2.36 or "Very Much Aware" while Family got the lowest mean of 2.31 or "Aware". It means that respondents are very much aware of the adverse effects of drugs in terms of health because they can cause long-term illnesses like lung cancer.

3. Correlating the level of awareness of the respondents on the adverse effects of drugs and their profile variables

Table 13

Test the relationship on the level of awareness of the respondents on the adverse effects of drugs and their profile variables

\begin{tabular}{|c|c|c|c|c|c|}
\hline & & Study & health & Family & behavior \\
\hline \multirow[t]{3}{*}{ Age } & Pearson Correlation & -.052 & -.071 & -.062 & -.076 \\
\hline & Sig. (2-tailed) & .574 & .438 & .502 & .406 \\
\hline & $\mathrm{N}$ & 121 & 121 & 121 & 121 \\
\hline \multirow[t]{3}{*}{ Gender } & Pearson Correlation & .033 & .001 & $-.185^{*}$ & $-.226^{*}$ \\
\hline & Sig. (2-tailed) & .720 & .989 & .042 & .013 \\
\hline & $\mathrm{N}$ & 121 & 121 & 121 & 121 \\
\hline \multirow[t]{3}{*}{ Civil Status } & Pearson Correlation &.$^{\mathrm{a}}$ & ${ }^{\mathrm{a}}$ &.$^{\mathrm{a}}$ &.$^{\mathrm{a}}$ \\
\hline & Sig. (2-tailed) & . & . & . & . \\
\hline & $\mathrm{N}$ & 121 & 121 & 121 & 121 \\
\hline \multirow{3}{*}{$\begin{array}{l}\text { Educational } \\
\text { attainment of } \\
\text { parents }\end{array}$} & Pearson Correlation & -.114 & -.064 & .012 & .024 \\
\hline & Sig. (2-tailed) & .211 & .485 & .899 & .791 \\
\hline & $\mathrm{N}$ & 121 & 121 & 121 & 121 \\
\hline \multirow{3}{*}{$\begin{array}{l}\text { Occupation of } \\
\text { parents }\end{array}$} & Pearson Correlation & -.037 & -.056 & .037 & .002 \\
\hline & Sig. (2-tailed) & .689 & .541 & .685 & .980 \\
\hline & $\mathrm{N}$ & 121 & 121 & 121 & 121 \\
\hline \multirow{3}{*}{$\begin{array}{l}\text { Gross monthly } \\
\text { income }\end{array}$} & Pearson Correlation & .005 & .038 & -.111 & -.128 \\
\hline & Sig. (2-tailed) & .960 & .677 & .225 & .162 \\
\hline & $\mathrm{N}$ & 121 & 121 & 121 & 121 \\
\hline \multirow[t]{3}{*}{ Ethnic group } & Pearson Correlation & -.064 & -.070 & -.126 & -.127 \\
\hline & Sig. (2-tailed) & .488 & .444 & .168 & .167 \\
\hline & $\mathrm{N}$ & 121 & 121 & 121 & 121 \\
\hline
\end{tabular}

- Correlation significant at 0.5 level

The table shows, there is a significant relationship between the gender variable of the respondents and their level of awareness of the adverse effects of drugs in terms of family and behavior. It implies that the awareness of the students of the adverse effects relative to family and behavior is influenced by their gender variables.

Further, the results in the table show that there is no significant relationship between the gender variable of the respondents and their level of awareness of the adverse effects of drugs in terms of education and health. 
4. Dimension/s where the respondents are not aware of

- Based on the results of the study, no dimension is rated low or found "not aware", hence, the level of awareness of the respondents on adverse effects of drugs relative to all dimensions is high which means they are aware of the ill effects of drugs in education, health, family and behavior. This will further manifest that the Out-of-school youth respondents are aware of the adverse effects of drug abuse and this is a good advertisement where drugs should not be taken out for some reasons like curiosity, experimentation, relieving problems, and or to escape reality.

5. Proposed measures to address the dimension where the respondents are not aware of.

- Since the study has no identified dimension which is rated low or "not aware", the researcher has no recommended measures to address the dimension where the respondents are not aware of, but for the agencies concerned to continuously perform their roles in the strict implementation of the drug law.

\section{DISCUSSIONS}

The findings of the study reveal the following:

1. Profile of the Respondents

- The mean age of the Out-of-School Youth respondents is 19.81 , males, single, and are Itawes speaking.

- The majority of the parents of the respondents are elementary graduates, farmers, and their monthly income is ranging from 100-10,000 only.

2. Level of Awareness of the Respondents on the Adverse Effects of Drugs

- Respondents are "Very much aware" of the adverse effects of drugs in terms of health.

- Respondents are "Aware" of the adverse effects of drugs in terms of education, family, and behavior, not closely supervised and doing misconduct, respectively.

6. Correlating the level of awareness of the respondents on the adverse effects of drugs and their profile variables

- The level of awareness of the respondents on the adverse effects of drugs is not influenced by their profile variables.

7. Dimension/s where the respondents are not aware of

- Based on the results of the study, there is no dimension of the study which is rated low or found "not aware", hence, the level of awareness of the respondents on adverse effects of drugs relative to all dimensions is high which means they are aware on the ill effects of drugs in education, health, family and behavior.

\section{Conclusion}

Based on the findings of the study, the researcher has concluded that Out-of-School Youth is 
"very much aware" of the adverse effects of drugs in terms of health since it can cause long term illnesses like lung cancer, while others are "Aware" of the negative effects in taking drugs, effect to the families and behaviors. Moreover, the result shows that even the OSY that sometimes others believed to be stubborn and can cause problems in the society are knowledgeable on the adverse effects of drugs and that this will further manifest that they cannot be easily recruited to join any group or gang who are into drug-using/taking. If this kind of youth is present in the community, there is no fear that drugs may proliferate and influence others.

\section{$\underline{\text { Recommendations }}$}

Based on the findings and conclusions of this study, the researcher proposed the following recommendations:

1. Strict monitoring of parents to their children especially the Out-ofSchool youth.

2. The Local Government to create a program for the Out-Of-School youth to be productive even they do not go to school.

3. The Local Government Unit must collaborate with other Government and Non-Government agencies to help the youth hasten their skills under the vocational program.

4. Lead agencies in the implementation of drug laws must be firm.

5. A similar study should be conducted to include other variables not covered by the study.

\section{REFERENCES:}

Abdulkarim, A.A, Mokuolu, O. A, and Adeniyi, A., (2005). Drug use among Adolescents in Ilorin, Nigeria. Tropical Doctor 2005; 35: 225 - 228

Ackard, D., Neumark-Sztainer, D., Story, M., and Perry, C. (2006). Parent-child connectedness and behavioral and emotional health among adolescents. American Journal of Preventive Medicine, $30(1), 59-66$.

Adam, J (1973). Understanding Adolescence: Current Development in Adolescent Psychology.Allyn and Bacon, USA.

Adelekan, M.L, Makanjuola, A.B., Ndom, J.E., Fayeye, J.O., Adegoke, A.A., and Amusan O (2002).5 yearly monitoring trends of substance use among Boarding Secondary School students' in Ilorin, Nigeria, 1988-1998. African Journal of Medicine

Aden, A. Dimlo E.A Ndolo, U.N \&Chinda, M.L (2006). Socio-economic Effects of Khat Chewing in North Eastern Kenya. East Africa Medical Journal.

Ali, R. (2010). Taking risks by examining our practice: Encouragement to address the couple relation. Clinical Child Psychology and Psychiatry, 15 (2), 147 - 150. British Columbia Council for Families, Canada (2009). Young Parents: The Importance of Support and Recognition.

Elizabeth B. R., Susan L. D, and Suman A. R. (2003) Preventing Drug Use among Children and 
Adolescents: A Research - Based Guide for Parents, Educators,

Escando, R. \& Galvez C. (2005). Free from Drugs and Addictions. Madrid: TalleresGraficosPerialara.

Retrieved June 15, 2010, from http://www.bccf.ca/all/resources/young-parents-importance-supportand-recognition

Retrieved May 20, 2010, from http://www.urban.org/publications/310486.html

https://doi.org/10.1016/j.healthpol.2008.11.011Get rights and content 